\title{
On the Verge of Institutionalisation? Participatory Budgeting Evidence in Five Italian Regions
}

\author{
Giovanni Allegretti ${ }^{1}$, Matteo Bassoli ${ }^{2}$, Greta Colavolpe ${ }^{3}$ \\ ${ }^{1}$ University of Coimbra, Apartado 3087, Largo Dom Dinis, 3000-995 Coimbra, Portugal \\ 2, 3 University of Padova, Via del Santo, 2835123 Padua, Italy \\ ${ }^{1}$ giovanni.allegretti@ces.uc.pt, https://orcid.org/0000-0001-6234-5168 \\ 2 matteo.bassoli@unipd.it, https://orcid.org/0000-0003-3601-9099 \\ ${ }^{3}$ gretacolavolpe@gmail.com, https://orcid.org/0000-0002-9060-9842
}

\begin{abstract}
Over the past few years, Italy has been setting the stage for different democratic innovations, especially those that have been implemented at municipal (or sub-municipal) level in different parts of the country. The expansion of Participatory Budgeting has been a remarkable one, accompanied by the diffusion of regional laws that were adopted to promote a culture of more intense civic participation. Moving from an overview of the recent diffusion of Participatory Budgeting in different areas of the country, this article proposes a reflection on what kind of added value the existence of this legal provision has led to the promotion of participation at a regional level and what this may represent. The construction of the Italian branch of Participatory Budgeting's World Atlas offers an opportunity to assess legal provisions' contribution to the diffusion and enrootment of participatory practices, especially in smaller-scale municipalities. Through zooming into some cases (such as Sicily, Emilia Romagna, Apulia and Tuscany, or Lazio in the last few years) the authors argue that the formalisation of participatory practices into legal frameworks today is an important but not a sufficient factor that diffuses and enroots participatory culture in local territories, and that a supplement of monitoring structures and detailed studies would help make challenges and added values of regional law frameworks clearer.
\end{abstract}

Keywords: participatory budgeting, institutionalisation, regional laws, participation incentives, citizens engagement, public policies, and civic engagement

JEL: 035, K30, N44, L38

For citation: Allegretti G., Bassoli M., Colavolpe G. On the Verge of Institutionalisation? Participatory Budgeting Evidence in Five Italian Regions. Financial Journal, 2021, vol. 13, no. 2, pp. 25-45. https://doi.org/10.31107/2075-1990-2021-2-25-45.

(c) Allegretti G., Bassoli M., Colavolpe G., 2021 


\section{INTRODUCTION}

In the last four decades, at least, there has been a growing emphasis in political rhetoric on the importance of providing spaces for citizen participation in policy making. More rarely, what has been defined as the deliberative or the participatory "imperative" [Blondiaux L. and Sintomer Y., 2009; Minson J., 1993] took the form of substantive changes in the normative frameworks, so that participatory involvement in decision-making could be progressively transformed into a "right" of citizens (both as individual and as communities). Such perspective is a visible component of those paradigms - as the struggles for the "Right to the City" - which look to participation as a central pillar to increase both the efficacy and the effectiveness of public policies, as their resilience and sustainability in facing an "era of growing uncertainties" [Stoker G., 2018], where rethinking governance in a more inclusive direction become a fundamental and unavoidable challenge of making representative institutions work better and with increased levels of perceived legitimacy and authoritativeness.

\section{Scarcity and variety of legal frameworks addressing participation}

Actually, in many countries and cultures, the judicial field (including its connections to the academic milieu) tends to ignore all praxes that are not already regulated by law, even if they are the object of significative investments in policies, projects and polity in general. Thus, demanding that lawmakers incorporate a certain degree of formalisation and institutionalisation in participatory and deliberative practices [Fung A., 2015], in order to trigger a "virtuous circle" [Ganuza E. and Francés F., 2012] where the interaction between "political willforce and the force of law" [Holz S., 2015] could: positively consolidate existing experiences, multiply the number and the democratic intensity of the diverse arena of citizen participation, and increase the substantiality [Geissel B., 2013] and incisiveness of those which can be defined as "Democratic Innovations" (DIs) [Smith G., 2009; Sorice M., 2019].

Indeed, such an interaction could help to reduce the frequent phenomenon which B. Santos and L. Avritzer [Santos B. and Avritzer L., 2007] have named as "the double disease of liberal democracy": i.e., the tendency of citizens reducing their commitment with all forms of participatory/deliberative practices as they are too dependent on elected/ representative officials and bureaucratic structures which they do not trust ${ }^{1}$. In fact, legal provisions which stress public institutions' obligations that involve citizenry in policy-making, could be imagined as indispensable tools to diminish the present dependence of Dls from an ancillary/subservient position in relation to the "discretionary goodwill" of institutional actors [Fernandes E., 2021], and to protect citizens' right to participation from political turnarounds or upheavals [Bassoli, 2018; Valastro A., 2016; Picchi M., 2012a; Ravazzi S., 2007]. Furthermore, the existence of more binding/mandatory legal frameworks - and an accurate monitoring of their concrete effects - could gradually consolidate the centrality of participation in legal culture [Allegretti U., 2006], fostering the diffusion of a favourable jurisprudence and court rulings that would further increase such centrality.

In the very few comparative studies that have been published in the last decade on this issue [Dias N. et al., 2019; Dias N., 2018; Sintomer Y. et al., 2013], the number of countries where legal provisions have been undertaken to support: the promotion,

1 In fact, in conditions of excessive interdependence between representative institutions and Democratic Innovations (with the latter in an ancillary position), civic engagement "looks like a waste of energy, worthy only for those who already have more effective "channels of incidence" at work so that their interests heard and incorporated in traditional decision-making" [Allegretti G. and Holz S., 2021]. 
expansion and consolidation of participatory processes are still limited. The broadness of legal provision diversity, also hinders a rigorous scientific comparison. Few legal measures have been conceived to turn citizens' participation into a mandatory/binding prerequisite for policy approval - and sometimes only in relation to single sectors of action. The latter has been the case of participatory budgeting in Peru, since 2003 [McNulty S., 2018]; in Dominican Republic, since 2006 [Allegretti G. et al., 2012]; in South Korea, since 2011 [No W., 2018], in Portuguese high schools, since 2017 [Abrantes P. et al., 2018], and in Angola, since 2019². The same has happened in the field of urban master plans of cities with over 20,000 inhabitants in Brazil, since the Law on the City Statute of 2001 [Fernandes E., 2007]. Conversely, in the majority of cases, legal frameworks prefer to set conditions to support "incentives" and "rewards" in participatory practices, activated in a voluntary form by local or supra-local institutions. This has been the case of Italian regional laws, the Ukrainian law and the Polish Law on Solecki Funds that have been promoting participatory budgets in rural municipalities [Bednarska-Olejniczak D. and Olejniczak J., 2018]. In some other cases, they have even favoured the creation of independent authorities that would be in charge of managing specific envelopes of funds to increase the "participatory" culture of a territory, especially in some sensitive areas of policy action (such as the Commission on Public Debate of France's case set in 1995 - CNDP) [Revel M. et al., 2007]. As synthetically suggested and reproduced by the Weberian guidance-scheme proposed by G. Allegretti and S. Holz (2021) (which represents some common ideal-types of regulatory interventions related to participatory practices), there are many ways in which "the Law", latu sensu, intervenes in the field of civic engagement with public policies and projects, trying to affect the functioning of participatory practices as well as their outcomes/ impacts. Within such a varied and complex panorama, marked by wide asymmetries and different duration of the experiments, comparative studies are almost inexistent, especially those targeting outcomes and impacts that could assess to what extent the different types of legal provisions have the capacity to promote the growth and dissemination of DIs in a specific territory, as well as to foster policy diffusion across country borders, triggering mechanisms of positive emulation [Oliveira 0., 2017]. Particularly, no study up to now has addressed the specific topic of the growth and diffusion of specific DIs in relation to the existence of normative frameworks related to the promotion of local participation in a certain territory, except in the case of the mid-term evaluation of Peru's national law on participatory budgeting that was carried out 6 years after its implementation [World Bank, 2010].

\section{Focus and expected contributions of this article}

The authors of this article seek to contribute to the ongoing debate on some of the abovementioned topics, providing an exploratory analysis of a specific country - Italy - which in the last few years has seen visible growth of a variate range of Democratic Innovations, and a parallel increase in the number of regional legislations aiming to promote a culture of participation within their boundaries. Namely, this article will focus on a specific family of Dls - called participatory budgeting or PB (which will be briefly described in the next paragraph) - whose characteristics are recurrent, thus configuring a "recognizable technology of participation" [Allegretti U. et al., 2010] which can be easily analysed in different contexts, despite the variety of models and micro-typologies which it has generated around the globe [Sintomer Y. et al., 2012] and in Italy itself [Sintomer Y. and Allegretti G., 2009; Bassoli M., 2012].

2 For the Presidential Decree see: https://www.pbatlas.net/uploads/7/0/6/1/70619115/decretos_presidenciais.pdf. 
This article has been conceived in line with the ongoing exploratory work of $\mathrm{OIBP}^{3}-$ the "Italian Observatory on PB diffusion", a grassroot-based structure stemming from the collaboration of different research groups and individuals based in Italy, who attended the World Atlas of Participatory Budgeting $2020^{4}$, with the aim of enriching the work done by URBES - Observatory on Urban policy (University of Padova) and the start-up BiPart in $2019^{5}$, in order to create a more evidence-based debate.

Specifically, this article will attempt to relate two phenomena which have been characterising the Italian contexts in the last 15 years: the approval of participatory regional laws (i.e., laws to promote the culture of citizens' engagement in public policies) and the spread of participatory budgeting experiences. Thus, the next paragraph will focus on clarifying why the two phenomena are both meaningful in literature and for the Italian context; the third paragraph will discuss an exploratory quantitative analysis proposed by OIBP [Stortone S. et al., 2021; Bassoli M. et al., 2021]; and the fourth will try to analyse its results and derive some conclusions on this form of institutionalisation of local participatory processes.

\section{THE ITALIAN CONTEXT: PARTICIPATORY BUDGETING BETWEEN THE FORCE OF WILL AND THE FORCE OF LAW}

\section{A brief characterisation of PB}

Participatory Budgeting (PB) represents a family of Democratic Innovations which has been considered among the most radical [Bassoli M., 2012; Fung A. and Wright E.0., 2002; Pateman C., 2012], as far as, simultaneously, it is an important tool of a "monitory democracy" [Keane J., 2018] and directly involves citizens not only in the discussion of problems and solutions for their living environments, but in the prioritisation and hierarchisation of proposals on the part of citizens. Thus, PB differs from many other methodologies, to the extent that it places the "money issue [...] in the first stage" of its procedural organisation, albeit not necessary "in the first place" of its core mission and interests [Allegretti G. and Copello K., 2018].

Under the label of PB, many different models of practices can be listed, with a diverse range of designs. Indeed, while expanding to other continents [Sintomer Y. et al, 2013], the original Brazilian model (marked by a complex architecture of thematic and placebased channels of social dialogue affecting a large portion of municipal budget [Fedozzi L., 2000; Allegretti G., 2003; Baiocchi G., 2005]) tended to change, hybridising itself through incorporating elements of deliberative practice suppor-ted by experts [Ravazzi S. and Pomatto G.F., 2017] and new spaces of participatory planning and projects' co-design [Stortone S. and De Cindio F., 2016]. PB also incorporated online tools [Nitzche P. et al., 2012; Allegretti G. et al., 2016], which often contributed to dilute its effort by favouring a just redistribution of public resources, to privilege majority-based methodologies of codecision, where decision tends to be more a "sum of individual preferences" than an output of consensus-driven methodologies.

Italy, since the beginning of its interest in PB [Allegretti G. and Herzberg C., 2004; Sintomer Y. and Allegretti G., 2009], until the last generation of experiences [Stortone S. and Allegretti G., 2018], well represents this large variety of sub-models, which took their peculiar shapes from the dialogue with a larger family of other participatory practices and subsidiarity-based decentralisation formulas, which - since the late sixties - marked the experimentation of democratic innovation in the country. Under this perspective, Italy contributed to the "transition" from the Brazilian models of PB to the creation of a more

\footnotetext{
3 See: https://oibp.bipart.it.

4 See: https://www.pbatlas.net/index.html.

5 See: https://bipart.it.
} 
European-based PB, which is today widely circulating around the globe, also due to cooperation-to-development European agencies and some international institutions of the UN system and the Bretton-Woods consensus [Baiocchi G. and Ganuza E., 2017; Oliveira O., 2017; Ganuza E. and Baiocchi G., 2012].

Italy, somehow, contributed a lot to the complexity of the PBs' variety - which is responsible for the wide discussion about the possibility, or not, of providing an unambiguous definition of this specific family of participatory processes; but this contribution was also helpful in clarifying the nature of "ideoscape" [Appadurai A., 1990] that can be recognised as PB: i.e., as a sort of adaptive model in permanent and an incremental evolution through the concretelyapplied variations provided by the original features. Therefore, only a methodologically-based definition can well represent the minimum common denominator behind the complexity of this ideoscape. The more convincing of such methodological definitions was given by EU-wide comparative research conducted by Y. Sintomer and colleagues, who paved the way for future international debate, by identifying five significative dimensions which, altogether, coexist in the majority of $\mathrm{PBs}^{6}$.

Today, the most recent censuses show that, worldwide, there are around 11,700 PB [Dias N. et al., 2019, p. 17]: approximately $62 \%$ of the processes are promoted by local governments, while almost $34 \%$ are supported by other entities, with a leading role of educational institutions - in particular public schools In Europe, there are around 4600 PB, with a clear prevalence (around $92 \%$ of the total) concentrated in Southern Europe, the Balkans and Eastern Europe. Almost all of these experiences tend to be locally-driven. At the moment, there is no ongoing experience at a national level PB [Falanga R. and Fonseca I., 2020], and only 9 regional governments are committed to promoting PBs on a regional level's competences: 5 of which in Poland, 2 in Portugal, 1 in Slovakia and 1 in Ukraine. At the same time, there is a growing number of regions (especially concentrated in Italy) that have been issuing legal frameworks that promote participation at a lower level - often for the sake of municipalities. Unlike in other continents, European countries have generally chosen to avoid mandatory impositions of partaking in PBs issued from national or regional, preferring a legal framework to support experiments and the creation of a participatory culture.

It is worth underlining that Participatory Budgeting is usually conceived as an informal process which relies on the political will of the governments and the social power of communities [Bassoli M., 2012], with an implicit or explicit reference to the centrality of participation in political life, as put forward by national constitutions. At the same time, a formal institutionalisation of their existence has often been viewed ambiguously: more as a risk of ossification, stiffening and bureaucratisation [Genro T., 1997] and a threat to their resilience and capacity of permanent adaptation and incremental development, rather than a guarantee of permanence and consolidation.

\section{Regulating participation in Italy: a fragile process?}

Italy, a country composed by 19 regions and two autonomous provinces (Trento and Bozen), started hosting PB experiences in 2002-2003 at a local level, following a series of interchanges between Italian local authorities with Brazil, in the aftermath of the first World Social Forum held, in Porto Alegre, in 2001 [Sintomer Y. and Allegretti G., 2009].

\footnotetext{
${ }^{6}$ The main 5 dimensions are: "(1) the financial and/or budgetary dimension must be discussed; participatory budgeting involves dealing with the problem of limited resources; (2) the city level has to be involved, or a (decentralised) district with an elected body and some power over administration [...]; (3) it has to be a repeated process (one meeting or one referendum on financial issues does not constitute an example of participatory budgeting); (4) the process must include some form of public deliberation within the framework of specific meetings/ forums; (5) some accountability on the output is required".
} 
With its strong neo-municipalist tradition that it has inherited after several centuries of institutional history - Italy counted 7,903 municipalities in 2020 - but the number is fast changing due to several fusion/merging processes. Citizen Participation is mentioned, as part of the multilevel protection of the rights to freedom of expression [Papa A., 2020], in Article 3 of the 1948 Constitution?. The latter - unlike other EU countries - dedicates a reduced space to the public administration's functioning [Allegretti U., 2010] and, thus, the notion of participation is not specifically mentioned again in relation to the construction of public policies. Nevertheless, as well depicted in the Encyclopedia of Law [Allegretti U., 2011] in the Italian legislation the word appears to have - at least - 14 concurrent uses: and their clusters of meaning encompass very different dynamics, referred to representative democracy functioning (including taking part in acts related to direct democracy), such as society's self-organising capacity to interact with political/administrative institutions and even the active use of subjective rights provided by public administrative procedures (such as access to administrative documents). Among other meanings, the increased use of the word "participation" serves to depict specific arenas which are imagined as a bridge between representative institutions and the inhabitants of specific territories: spaces of interaction, which are conceived as a "non-state public sphere" [Genro T., 1997] where citizens could "have access to the State without mediations" while "maintaining their autonomy". The latter which coincides with the definition of "democratic innovations" used in social sciences [Sorice M., 2019] - well highlight how the concept of participation constantly crosses the notion of democracy and other as citizenship, subsidiarity and cooperation, with overlapping areas and different meanings depending on contexts and cultural perspectives from which they can be read from [Moro G., 2020].

The Italian DIs also include a sub-family of deliberative practices [Bifulco R., 2011] such as citizens juries or panels, deliberative polls and other "mini-publics" [Sintomer Y., 2007; Fishkin J., 2018] - that aim to improve the argumentative quality of civic participation and the effectiveness of interactions between lay and expert knowledge ${ }^{8}$. In Italy - as in other Southern European countries - such practices are much less developed than in Central and Northern European context. In this article, we will consider them as types of participatory practices, as we focus mainly on participatory budgeting and in Italy some "hybrid experiences" of PB can be found where deliberative spaces (for example, based on random selected procedures) were introduced on the baseline ranking and voting procedures [Ravazzi S. and Pomatto G., 2017; Stortone S. and De Cindio F., 2016].

The large and creative history of models and sub-typologies of Participatory Budgeting in Italy, for several years has rarely crossed over the path of formal institutionalisation procedures, as their experimentation has seemed rooted more in the "goodwill" of political implementers than in "the force of law" and of formal procedures [Holz S., 2015]. When this had happened at a municipal level [Sintomer Y. and Allegretti G., 2009, p. 120] the formal provision had proved to have no real strength: the formalisation of commitments seems to have a lower value than the political goodwill. A representative case is that of the city of Pieve Emanuele, which introduced PB in the Municipal Statutes in $2003^{\circ}$, that attempted to permanently

\footnotetext{
7 See: https://www.senato.it/documenti/repository/istituzione/costituzione_inglese.pdf.

8 Such practices (often based on the use of different modalities of random-based or sociologically-stratified selection of participants) are generally imagined as methodologically refined, expensive and related to an ideal of "representativity" of complex social environments through small and "easy-manageable" samples of citizens: but, in relation to the previous generation of participatory practices, they were also detached from the real incising capacity in the socio-spatial transformation of the territories where they took place, often becoming laboratory-operations that have a much reduced political impact and a limited scope. See: [Bächtiger et al., 2018].

9 See: Art. 85 (restored as it was in 2016): https://www.comune.pieveemanuele.mi.it/upload/pieveemanuele/ gestionedocumentale/STATUTO_784_1994.pdf.
} 
safeguard the right to participation in local budget construction ${ }^{10}$ : but when, in 2007, the majority shifted to a centre-right administration, the PB process was abolished, despite its permanence among the self-obligations that the mayor established in the Municipal Statute. The case well describes how the formalisation could have no formal effect on keeping an experiment alive in the absence of community engagement in order to make its voice be heard, and of a progressive juridical culture animated by courts and judges that proved interested to see the rights to participation enforced, in spite of the conjunctural and discretional will of ruling majorities. A similar case - at another administrative scale - happened with Lazio Region's Financial Law n. 4/2006. Despite its Article 50 (that is still currently enforced) provided contributions to municipalities and provinces of Rome for the activation of forms of participation, through the creation of a specific budget channel| ${ }^{11}$, when in October 2009 the right-wing coalition was elected, it ignored the entire set of participatory procedures. Their formal existence did not constitute an obstacle for the government to stop the participatory experimentations, the following centre-left coalition did not re-active the process. Despite this, a study promoted by Rome III University in 2013 [Angeloni L. et al., 2013] showed that the promotion of almost 200 PB experiences between 2006 and 2009 [Allegretti G., 2011a] although not being able to guarantee the continuity of all the experiments that had been triggered - maintained important impacts on several local institutions, which continued some participatory practices and informal networking of mutual learning and support. Somehow, these types of outcomes reveal a sort of "incomplete proceduralisation", which in the absence of supportive communities which demand the respect and enforcement of rules, and representative of the judiciary power who get responsibilised for leveraging citizens' participation as a central tool to guarantee Constitutional values such as freedom and equality [Picchi M., 2012a] - contributing to the reduction of its effectiveness, limiting its enforcement only to "good practices entrusted to contingent political sensitivities" [Valastro A., 2016]. Indeed, the Italian experience in formalising participatory processes has to deal with a very unsatisfactory attempt that dates back to the seventies, and negatively marked the political debate in the following decades, constantly re-emerging as a caveat of possible failures during all discussions that take place around the challenge of "formalisation" [Massarenti F., 2017]. The experience refers to the creation of Law 278/1976, through which lawmakers tried to somehow rescue the visible delays of Italian legislation by adapting to the recognition of an active role of citizens in the administrative procedure [Allegretti U., 1996], which - already since the fifties - had shaped a multifaced and "cubist" panorama of participatory practices, which had found their privileged spaces in schools, universities, neighbourhood civic centres and factory councils. The Law 278 - that institutionalised some decentralisation practices through participation experimented in several municipalities subordinated them into a stiff series of electoral rules, projecting the centrality of the party system on the pre-existing fluid system of civic engagement [Vandelli L., 2015], almost paralysing all the benefits of previous practices, and reinforcing the ambiguity of the relations of autonomy and dependence between the structures of social selforganisation and the hyper-formalised institutional politics [Sintomer Y. and Allegretti G., 2009, pp. 109-110]: and is not a surprise that - when municipal decentralisation was strongly reformed and partially abolished by Italian Government between 2008 and 2010 almost no grassroot forces defended the existing configuration, revealing the absence of ownership of that ossified and bureaucratised system [Allegretti G., 2011a]. These events helped to explain why all the subsequent proposals of institutionalisation of participation in Italy have not received a large amount of support, and haven't been

\footnotetext{
${ }^{10}$ See: [Sintomer Y. and Allegretti G., 2009, p. 120].

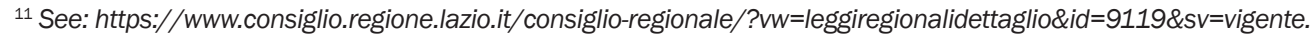


considered indispensable - except in a "light" form of eventual incentives and recognition of self-supporting practices derived from a voluntary experimental environment.

\section{WHEN REGIONAL LAWS SUPPORT PARTICIPATORY BUDGETING}

\section{An overview of Italian regional laws that promote participation}

In Italy, the interest in participatory budgeting as an innovative and effective type of practice that involves citizens in the construction of their territories and the quality of their daily life, first started in 1998 (after an article on Porto Alegre's PB in "Le Monde Diplomatique"), and quickly developed thanks to a network of political-administrative progressive institutions, research centres and civic organisations, which gathered around the "Charter for a New Municipium" (Porto Alegre - World Social Forum 2002). In Italy, the debate around the charter, in 2003, led to emergence of the New Municipium Network (ARNM), a no-profit civic/political platform linking local authorities, territorial associations and academic experts, of which the spread of PB in the country is strictly interconnected with [Allegretti G. and Allulli M., 2007; Rispoli F., 2012]. Since 2004, ARNM included a thematic group of progressive provincial and regional politicians (mainly from Tuscany, Apulia, Lazio and Emilia Romagna), which promoted events focussed on PB in their territories, and launched mutual learning and support activities, to imagine a scaling-up of participation from local to higher administrative levels and to promote lobbying for it, within their governing coalitions As far as it refers to local practices, since the beginning the discussion among the regional representatives within ARNM had an added goal: that of taking advantage of being the Regions "legislating organism" with access to several avenues to funds which could be used as a leverage to trigger a larger use of participatory budgeting by Provinces and Municipalities. However, the debate within the ARNM took a peculiar turn, that shifted the attention from the need for regions to experience themselves as relevant forms of participation based on their competence, to the idea that they had primarily focused on creating systems of incentives and support to other infra-regional public entities. Under this perspective, it is true that the regional laws that took shape in Italy after 2006 constitute a new phenomenon, as they are specifically "dedicated" to promote participation [Sgueo G., 2011; Valastro A. and Carlone U., 2019].

PB had been more central in the region's first experience that adopted legal and policy measures to incentivise participation, as did the Lazio Region (5.7 million inhabitants). Even if the word "participatory budgeting" didn't appear on the scale of which Article 44 and 50 of Regional Law 4/2006 (as well as the subsequent Law n. 5/2006) ${ }^{12}$ specified the need for a larger amount of participation in the budgetary procedures and economic choices of the Region itself and of the local authorities which wished to receive added regional support to elaborate on their participatory experiences. Consequently, The Special Office created in the Regional Ministry of Finance, Budget and Participation which support participatory processes at local level (which had not foreseen what the law would become) has oriented the majority of experiences toward the creation of PB's "hybridised" experiences. Furthermore, the same office, every year between 2006 and 2009, organised a region-wide process to debate a 5 million euro envelope, using semi-deliberative methodologies which included a component of random-selection of participants living in different parts of the regional territory.

The following year, the Tuscany Region (made up of 3.6 million inhabitants) approved the Law n. 69/2007, after one year of itinerating social dialogue and a town-wide meeting, codesigned with interested citizens and some random-selected inhabitants of the region [Floridia F., 2013; Bortolotti F. and Corsi C., 2012]. The Tuscan Law put no emphasis on

${ }^{12}$ See: http://www.regione.lazio.it/binary/rl_bilancio/tbl_normativa_svileconomico/LR_4_280406_LeggeFina nziariaEsercizio2006.1234353547.pdf. 
budgetary issues, but hinged on two main innovations: the creation of an independent authority ${ }^{13}$ (with a fixed budget to incentivise participatory processes around the regional territory) and the creation of a new procedure - inspired by the French Dèbat Public that could be used in important projects and public work. During the first 5 years, PBs had represented 7 out of 52 co-funded processes (around 13\%), although in some years almost $30 \%$ of the proposals had been presented to the annual bid [Picchi M., 2012b]. The first 7 funded PB practices were very different in size, quality and also in terms of resources they put at stake [Picchi M., 2012b, p. 284]. After Law n. 69/2007 was replaced with law n. 46/2013 [Lewanski R., 2013; Allegretti G. and Casillo I., 2015], PB became even less central and visible, the previous years had demonstrated that many PB experiences were carried on only when regional support was in place, thus demonstrating they were backed by a reduced political will to invest in them, and appeared more like an "excuse" to grasp a light commitment in order to receive regional added resources. This critical perspective well justified in the annual reports by the APP's member, and in the final evaluation of the 5 years period - explains why between 2014 and 2019 ${ }^{14}$, the 6 supported PBs (especially the 3 funded after 2015) were mainly hybrid processes, and why the region requested a midterm visible commitment from the municipality, in order to avoid a "one shot" experiment, and therefore, respecting the PB's nature of a cyclical/repeated process.

The third region which created a legal framework to consolidate and spread a culture of participation was Emilia Romagna (composed of 4.4 million inhabitants), which - was inspired by Tuscany's - approved Law n. 3/2010 [Sgueo G., 2011]. The Law, mainly focussed on setting up a system of incentives for different actors, that created a Regional Technical Office (as in Lazio's case), which assesses "project proposals" of participatory processes that come from different actors/institutions and will be supported by a regional fund ${ }^{15}$. A large process of collective assessments of the law's impacts and challenges in 2017-2018 led to the approval of a new legal framework (Law n. 15/2018), which resembles the previous one, but strengthens the regional commitment by supporting innovative participatory and deliberative experiences, (almost doubling the financial resources involved). Between 2010-2017, 19 PBs were funded ${ }^{16}$.

The experience undertaken in the Sicily Region (4.8 million inhabitants) appeared to be quite different, following the intense work of advocacy on participatory approaches brought into the political debate by a new political force called the " 5 Stars Movement", whose presence in the Italian political scene became very visible after the 2013 general election [Stortone S. and Allegretti G., 2018], as they had an important presence in different Sicilian institutions. The Sicilian approach to institutionalisation of participatory practices focussed specifically on PB, and chose to, somehow, make a mandatory portion of regional funds that are annually transferred to local institutions. Law n. 5/2014 ${ }^{17}$ required that municipalities assign at least $2 \%$ of funds to capital expenditures coming from regional transfers, to implement projects co-decided "with forms of participatory democracy [...] that involve citizens in the choice of useful actions for the common interest" (art. 6). Formally, if a local government fails to organise PB in a given year, the following financial year would have to refund the corresponding value to the Region. The law was later clarified with a directive (Explanatory Circular n. 5/2017) stressing that the funding must be used to

\footnotetext{
${ }^{13}$ See: $h$ ttp://www.consiglio.regione.toscana.it/partecipazione.

${ }^{14}$ See: $h t t p: / / w w w . c o n s i g l i o . r e g i o n e . t o s c a n a . i t / o i / d e f a u l t ? i d c=47 \&$ nome=aut_rapporti.

${ }^{15}$ The Office is not an "independent authority" as in Tuscany, but is coordinated by an appointed high rank regional manager. See: https://partecipazione.regione.emilia-romagna.it/tecnico-di-garanzia/chi-siamo.

${ }^{16}$ See: https://www.osservatoriopartecipazione.it/processi/tematica-specifica/bilancio-partecipativo/6.

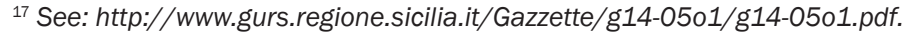


implement projects and not to manage the participatory practice, while some criteria and thresholds were later established by Law n. 8/2018 in order to set exceptions as a general rule for some types of local authorities ${ }^{18}$. Although the Regional Ministry of Local Autonomies and Public Services are in charge of supervising the compliance of legal provisions and to report annually on the achievement of its goals. A supporting structure to monitor, assess and improve the quality of the practices has not yet been established.

The last region to adopt a law for participation was Apulia (consisting of 3.9 million inhab), whose Law n. 28/2017 was challenged by the National government in the Constitutional Court ${ }^{19}$, Apulia's final decision - although it had erased some parts of the law that seemed to overlap with State competences - has been a very important and positive encouragement to Italian political authorities to intensify efforts to expand participatory processes that support policy-making. The Apulian Law, which recognises participation as a right and a duty of the citizenry, comes after more than a decade of committed regional policies that promote participatory and deliberative experiences, especially in the field of territorial planning and youth policies: therefore, it can be read as a formal consolidation of a pre-existing solid engagement, which can multiply local experiments, and strengthen the construction of a diffuse participatory culture, stimulating multiscalar and transcalar innovation in polities. The construction of a dedicated portal collects all the descriptions of and links to the different co-funded processes ${ }^{20}$, is a clear tool which monitors such challenges: it also reveals that, compared to other regions, Apulia increased the level of commitment by applying participatory approaches also to its own regional competences and sectoral policies.

Finally, it is worth underlying that - according to their statutes [Bobbio L., 2017; Sgueo G., 2011] - other regions in Italy have been creating a normative framework for participation, but (in Umbria's case with Law n. 14/2010), they were mainly concentrated on regulating traditional tools of direct democracy (such as referenda, petitions, laws of grassroot initiative), so this article does not consider them as relevant in the promotion of participatory practices and a culture of civic engagement in policy-making. Similarly, the experience of the Autonomous Trento Province is not considered either, as its Framework Law on Participation n. 3/2006 - despite having supported the gradual creation of an Authority for Participation (instituted by Law n. 12/2014 ${ }^{21}$ ) - is concentrated on a peculiar structure of valley-communities, which is not comparable with other territories, and does not fit with the purpose of this reflection.

\section{Setting the problem and creating a methodology}

The above-mentioned overview on Italian regional laws on participation clearly illustrates the existence of a high triggering diffusion potential of participatory processes of different natures and administrative levels, as the absence of specific comparative studies which could verify their impact on different typologies of Democratic Innovations. How do these dynamics impact the diffusion of Dls which are potentially more radical in nature, such as $\mathrm{PB}$, which involve an explicit and tight relation with investments and public spending?

Here, the authors would like to propose an exploratory analysis focussed on PBs, which is asymmetrically present - as a specific method - in the regulatory framework of the main Italian regions which passed legislation on participation. It will take into account the number of trackable experiences in 2019, with some insight from the 2006-2019 period. This narrow

\footnotetext{
${ }^{18}$ See: http://www.edizionieuropee.it/LAW/HTML/211/si5_03_470.html.

${ }^{19}$ See: Court Ruling n. 235/2018 - https://www.cortecostituzionale.it/actionSchedaPronuncia.do?anno=2018 \&numero=235.

${ }^{20}$ See: $h$ ttps://partecipazione.regione.puglia.it/.

${ }^{21}$ See: https://apl.provincia.tn.it/.
} 
focus and its time reference derive both from a general constraint (the fact that only in recent years, in Italy a census of PB was consolidated, and a similar analysis do not exist for other typologies of deliberative and participatory processes) and from the fact that only since 2018 - with the new Law of Emilia Romagna and Apulia, and the change of the Sicilian Financial Law - there is a more significative and consolidated panorama which allows a broader analysis of the Italian context, in relation to the possibility of reading the gradual effects produced by these frameworks on participatory practices. Taking into account that no regional legislation commits the issuing entity to practice PB on its administrative level, the proposed analysis will focus on municipal PB experiences. The year 2020 has been excluded, as many PB were suspended or delayed their cycles to 2021, and data collected at the end of 2020 was not reliable.

The main question which guides the exploratory analysis is verifying whether the growth of PBs in Italian municipalities has been benefitting institutional incentives and/or pressure generated by regional legislation, observing the existence of positive correlations between the number of existing PBs and the existence of supra-municipal frameworks that establish rules to incentivise (as in Lazio, Tuscany, Emilia Romagna and Apulia's case) or make PB a mandatory prerequisite for all and/or for certain types of local authorities (as in the Sicily's case).

To this aim, a mixed method approach was deployed, through literature review, mapping and semi-structured interviews. Given the size of the whole sample (almost 8,000 municipalities) we set a sampling frame that excluded municipalities below 2,000 habitants. The exclusionary criterion relates to the reduced presence of PB practices among small municipalities [Sintomer Y. and Allegretti G., 2009], as confirmed by all the regional reports linked to the existing offices and authorities for participation analysed for the years preceding $2017^{22}$. To produce the dataset for the years 2006-2019, the first step was to collect all information from existing grey and academic literature - reports, scholarly articles and databases [Stortone S., 2019; Allegretti G. and Stortone, 2014; Sintomer Y. et al., 2012]. Existing literature, rich and wide although intermittent, detects empirical cases dated back from as far as 1994 [Bassoli M., 2012]. However, the data is not fully consistent given that it has been limited to selected research without a consistent mapping procedure with common established prerequisites. As for the second step, the authors deployed a purposive mapping of all existing practices focusing on 2018 and 2019, and later implemented some semi-structured interviews as a third step.

As for the mapping, eligible municipalities were split in two groups: those having more than 3,000 inhabitants using a randomised process of mapping, and those between 2000 and 2999 (added as the enlarged sample) ${ }^{23}$. The mapping protocol considered that national rules state that every municipality must have its own website, and BP is a type of practice which needs to be advertised in all possible forms, thus allowing the hypothesis that every existing BP had been advertised online. The search produced two reports allowing a quali/quantitative analysis: a spreadsheet on the presence/absence of BP and a collection of documents with qualitative information about each experience. The former were analysed using "chi square" to determine if the distribution of PB were correlated with the presence of regional laws (as an aggregate), or of a specific law. Special attention was devoted to a group of smaller municipalities, assuming that - if any PB exists their usually limited budget would have acted as a leverage to interact with regional provisions to promote participation in their territory. To this aim, personal communications

\footnotetext{
${ }^{22}$ The latter are often excluded by the obligations of the Sicilian Law, as the transfers of capital funds of the region are often under the new threshold of 10,000 euro (corresponding to $2 \%$ of those funds) established by the modifications introduced by Law n. 8/2018 to art. 6 of Law n. 5/2014.

${ }^{23}$ The additional research was conducted by G. Colavolpe for her thesis (between August and December 2020).
} 
were established with each municipality, and semi-structured interviews with mayors or mayors' offices were scheduled ${ }^{24}$.

\section{Some results}

The Atlas dataset [Bassoli M. et al., 2021] (improved with an added analysis of smaller municipalities) filled a visible void, which anchored the start of the discussion about the impact of regional laws on the diffusion of PB practices. According to the database, 121 municipalities - scattered throughout the county in an uneven manner - implemented a PB in 2019 (3\% out of the 4,050 municipalities analysed). Undoubtedly, the size of the regions had an impact on the results, which reveal no occurrence in those which have only a few dozen of municipalities above 2,000 inhabitants (like Aosta Valley, Molise, Umbria, Basilicata and Trentino-South Tyrol). Most regions have an occurrence record between $1 \%$ and $2,9 \%$, being that Sicily scores $22.7 \%$ (Table 1 ).

Table 1

\section{Number of PBs by region, and percentage of municipalities with PB} (out of the eligible cases)

\begin{tabular}{|l|c|c|c|}
\hline \multicolumn{1}{|c|}{ Region } & PB & Municipalities & Occurrence \\
\hline Abruzzi & 1 & 100 & $1.0 \%$ \\
\hline Aosta Valley & 0 & 15 & $0.0 \%$ \\
\hline Apulia & 4 & 209 & $1.9 \%$ \\
\hline Basilicata & 0 & 54 & $0.0 \%$ \\
\hline Calabria & 2 & 196 & $1.0 \%$ \\
\hline Campania & 1 & 328 & $0.3 \%$ \\
\hline Emilia-Romagna & 7 & 245 & $2.9 \%$ \\
\hline Friuli-Venezia Giulia & 1 & 115 & $0.9 \%$ \\
\hline Lazio & 5 & 199 & $2.5 \%$ \\
\hline Liguria & 2 & 89 & $2.2 \%$ \\
\hline Lombardy & 20 & 822 & $2.4 \%$ \\
\hline Marche & 0 & 124 & $0.0 \%$ \\
\hline Molise & 0 & 27 & $0.0 \%$ \\
\hline Piedmont & 5 & 329 & $1.5 \%$ \\
\hline Sardinia & 2 & 159 & $1.3 \%$ \\
\hline Sicily & 63 & 277 & $22.7 \%$ \\
\hline Tuscany & 4 & 193 & $2.1 \%$ \\
\hline Trentino-South Tyrol & 0 & 114 & $0.0 \%$ \\
\hline Tuscany & 4 & 193 & $2.1 \%$ \\
\hline Umbria & 0 & 51 & $0.0 \%$ \\
\hline Veneto & 4 & 404 & $1.0 \%$ \\
\hline Total & 121 & 4005 & $3.0 \%$ \\
\hline
\end{tabular}

Source: compiled by the authors.

Considering the 5 regions which have passed laws on participation by force for several years (i.e., Emilia Romagna, Tuscany, Apulia, Sicily and Lazio) a "chi square" test helps to answer the research first question, revealing a clear correlation between the adoption of PBs and the sole presence of a law. The contingency table created (see Table 2) using STATA provided with the distribution of the PB was divided into two groups (with or without a regional law). Odd-ratios served to inform about the effect of size on the law's impact.

${ }^{24}$ All online interviews were conducted in January and early March 2020 and recorded. Later on, they were transcribed and coded using NVIVO ${ }^{\text {TM }}$. See Annex 1 for further details. 
Hp. testing on all the regional laws $(\mathrm{chi} 2=103.95, \mathrm{p}<0.001)$

\begin{tabular}{|l|c|c|c|c|}
\hline & Presence of the law & Absence of the law & Total & Exposure (index) \\
\hline Presence of PB & 83 & 38 & 121 & 0.6860 \\
\hline Absence of PB & 1040 & 2889 & 3929 & 0.2647 \\
\hline Total & 1123 & 2927 & 4050 & 0.2773 \\
\hline & Point estimate & \multicolumn{3}{|c|}{$[95 \% \mathrm{Cl}]$} \\
\hline Odds ratio & 60674850 & \multicolumn{3}{|c|}{$0.75329650 .214443 \quad$ (exact) } \\
\hline Attr. frac. ex. & 0.8351871 & 0.8914747 (exact) \\
\hline Attr. frac. Pop & 0.5728969 & \multicolumn{3}{|l}{} \\
\hline
\end{tabular}

Source: compiled by the authors.

The analysis of the contingency table reveals that, out of 121 municipalities which adopted PB, 83 were concentrated in the regions with a participatory law (which sum up 1123 municipalities above 2,000 inhabitants), while other 38 PBs were implemented by municipalities spread in regions with no laws which promoted participatory processes (out of 2927). Therefore, it is (statistically) plausible to confirm that there is a relationship between the adoption of Participatory Budgeting and the presence of a law for its promotion. The "chi-squared" test confirms that there is a probability of less than $0.1 \%$ that this is due to chance, thus rejecting the null hypothesis. As for the odd-ration it scores 6.07: there are six times more possibilities of seeing a PB adopted in municipalities located in regions with a participatory law than in those without law.

However, given the variety of laws, hereinafter described, the same analysis was repeated for each region, independently. The authors thus found that in 2019 the only region which was positively affected by the law on PB creation was Sicily, where the higher level of political coercion, and a specific emphasis on PB can be found. In fact, out of 121 PBs, $63(52 \%)$ are concentrated in Sicily (out of 277 municipalities), so that there is less than $0.1 \%$ probability that this situation is produced by chance alone. Having a cogent law seems to increase the possibility of finding a participatory practice by almost 19 times (18.85), in relation to a non-Sicilian context (see Table 3).

Table 3

Hp. testing on all regional laws $(\mathrm{chi2}=400.40, \mathrm{p}<0.001)$

\begin{tabular}{|l|c|c|c|c|}
\hline & Sicily & Other regions & Total & Exposure (index) \\
\hline Presence of PB & 63 & 58 & 121 & 0.5207 \\
\hline Absence of PB & 214 & 3715 & 3929 & 0.0545 \\
\hline Total & 277 & 3773 & 4050 & 0.0684 \\
\hline & Point estimate & \multicolumn{3}{|c|}{ [95\% Cl] } \\
\hline Odds ratio & 18.85635 & \multicolumn{3}{|c|}{0.920726140 .964458 (exact) } \\
\hline Attr. frac. ex. & 0.9469675 & \multicolumn{3}{|c|}{} \\
\hline Attr. frac. Pop & 0.4930492 & \multicolumn{3}{|c|}{} \\
\hline
\end{tabular}

Source: authors' calculations.

Even though the data collected from 2006-2019 is not fully consistent [Bassoli M. et al., 2021], the authors decided to run a similar analysis (see Annex 2) to control the existence of similar patterns in other periods. Despite limitations, the analysis provides insightful information for the research question, also considering the timing of the different laws. Table 4 presents a summary of these analysis: the first column provides the size of each region, thereafter in each column there are a number of PBs divided per year (see next comment in grey the years covered by the regional legislation). 
Hp. testing on all regional law in each year

$\left({ }^{*} p<0.05, * * p<0.01, * * * p<0.001\right)$

\begin{tabular}{|l|c|c|c|c|c|c|c|c|c|c|c|c|c|c|c|}
\hline & $\begin{array}{l}\text { Munici- } \\
\text { palities }\end{array}$ & 2006 & 2007 & 2008 & 2009 & 2010 & 2011 & 2012 & 2013 & 2014 & 2015 & 2016 & 2017 & 2018 & 2019 \\
\hline Apulia & $5,16 \%$ & 0 & 1 & 0 & 0 & 0 & 0 & 0 & 1 & 0 & 1 & 3 & 4 & 4 & 4 \\
\hline $\begin{array}{l}\text { Emilia } \\
\text { Romagna }\end{array}$ & $6,05 \%$ & $4 * * *$ & $4 * *$ & $6 * * *$ & $3 *$ & $4 * * *$ & 2 & 2 & $7 * * *$ & 4 & 4 & 4 & 9 & 9 & 7 \\
\hline Lazio & $4,91 \%$ & 0 & $6 * * *$ & $10^{* * *}$ & $8 * * *$ & $5 * * *$ & $5 * * *$ & 2 & 2 & 2 & 3 & 1 & 1 & 5 & 5 \\
\hline Tuscany & $4,77 \%$ & 0 & 0 & 1 & 1 & $3 * *$ & $4 * * *$ & $6 * * *$ & $6 * * *$ & 1 & 2 & 1 & 2 & $1^{*}$ & 4 \\
\hline Sicily & $6,84 \%$ & 0 & 0 & 0 & 0 & 0 & 0 & 0 & 2 & 4 & $11^{* * *}$ & $28^{* * *}$ & $41^{* * *}$ & $44^{* * *}$ & $63^{* * *}$ \\
\hline $\begin{array}{l}\text { Rest of } \\
\text { Italy }\end{array}$ & $72,27 \%$ & 3 & 7 & 6 & 4 & 4 & 6 & 4 & 9 & 18 & 16 & 39 & 38 & 50 & 38 \\
\hline Totali & & 7 & 18 & 23 & 16 & 16 & 17 & 14 & 27 & 29 & 37 & 76 & 95 & 113 & 121 \\
\hline
\end{tabular}

Source: authors' calculations.

The exercise highlights some crucial features. For example: Tuscany ruled in 2007 and had a high rate of PBs between 2010-2013; in Emilia Romagna a movement of interconnected municipalities, inspired by visible examples as Modena, Reggio Emilia or Parma [Sintomer Y. and Allegretti G., 2009], of which anticipated the law. Therefore, in Emilia Romagna, one could wonder if the law n. 3/2010 is not the consequence of a massive wave of local experiences of participation, and to what extent the laws have been able to install (or not) a "virtuous circle" that led to significant hybrid innovative experiences, as can be considered those such the PB of Municipal Associations of Faenza $\operatorname{area}^{25}$ or the Bologna capital-city experiment. The latter - since 2017 [Stortone S. and Allegretti G., 2018] - started dialoguing with other processes of participatory planning and outstanding practices of shared management of commons [De Nictolis E. and laione C., 2016; Ciaffi D., 2019]. The effects of Lazio Law (issued in 2006) remained very visible at least from 2007 up to 2011, showing a "mid-long wave" of impacts, despite that the law was concretely disrespected after 2009 [Allegretti G., 2011b; Angeloni L. et al., 2013]. In Sicily, since the year after the law was approved (in 2014), there was a higher rate of probability of seeing a PB implemented than in any other region. Notably, the Apulia law still did not produce any statistically remarkable effect in terms of PB: this is no surprise, as far as the law consolidated specific previous-existing trends and policies which were mainly centred on topics linked to youth policies, sustainability and circular economy.

\section{LOOKING BEYOND THE MAPPING EXERCISE}

Given that historical series of reliable data about Italian PBs are not homogeneous, and due to the visible differences that exist among the Italian regional laws, a mapping exercise can only be an exploratory way to anchor future analyses of certainty: that, also in Italy, PB diffusion at local level has its own peculiar dynamics, as shown by a growing amount of literature [Sintomer Y. and Allegretti G. 2009; Bassoli M., 2018; Stortone S. and Allegretti G., 2018], but can be significantly influenced by the presence of measures conceived elsewhere to favour the expansion of participatory practices. Such measures, in Italy, usually are not merely discretionary policies put in practice by regional governments, but tend to be innovative legal frameworks. The ultimate goal is to "stabilise" citizen participation as a pivotal element of a political/administrative culture, as well as to increase the government

\footnotetext{
${ }^{25}$ See: https://partecipo-romagnafaentina.it/.
} 
legitimacy. However, many of these laws tend to trigger the political trust in local authorities, as if they offer local government tools and resources to produce social dialogue. At the same time the laws do not challenge the regional governments in the same direction, or at least with the same intensity.

Obviously, mere mapping cannot explain several micro-phenomena which characterise the changing geographies of participatory practices, especially when the laws do not privilege one or more specific typologies of participatory and deliberative processes, but conversely - they value innovation and hybridisation among diverse Dls. As the concept of innovation itself is often implemented by regions in "absolute terms" (privileging what is unusual or still unexperienced in general, but especially in the regional territory), this continuous pressure on cities has produced new forms and methods that involve citizens in public policies. This explains why, in each region, one can identify a series of new "waves" of Dl's typologies ${ }^{26}$ which tend to continuously substitute the previous ones.

Therefore, it is no surprise that the most effective regional provisions which have promoted PB's diffusion were those of Lazio and Sicily. Both laws are less complex (one article in financial law) and focus on triggering PBs implementation, via promoting its peculiar features (like involving citizens in the prioritisation of investments and in co-decision). These changes have been incorporated by all processes, independently of the pre-existing participatory model that they initially used to respond to law requirements. As two Sicilian mayors clarified (Int. 4 and 6), in the first few years after the Sicilian Law's approval (2014-2017), PB was not very common, and municipalities often opted for using existing participatory institutions or even informal consultations; but, gradually, there has been collective learning that has matured various processes toward more structured PBs. Such a transformation was made easier by the clarifications that the regional government with explanatory circulars offered, and then with Law 8/2018, that partially modified Article. 6 of Law 5/2014.

The above-mentioned testimonies also help to "relativise" the affirmation that the Sicilian Law looks more effective having chosen a mandatory model, while the others are based on incentives and rewards. In fact, the Sicilian obligation to use $2 \%$ of the regional transfers on capital investments to fund a PB procedure tends to be regarded, by mayors, as a way to allocate some "extra-funds" (defining them as "incentives" or "extraordinary contributions") [Int. 3], which can be revoked if mayors do not respect the due requirements. The absence of a real mandatory mechanism implemented by the region to turn participation into a real prerequisite of political management (instead of a prerequisite just for a bunch of choices linked to a residual pot of resources) [Int. 6] is made clear by the fact that - after six years from Law n. 4/2019, municipalities involved in PB are only around 1/5 of the total amount. This occurs despite the region having exerted its due control on the respect of the Law, as proved by the 2 million (out of the 6 that were distributed to municipalities in relation to the law) which were revoked in 2020 because they had not been used according to a co-decisional procedure of citizens participation ${ }^{27}$.

In this perspective, it is worth stressing that - unlike other regions that tended to "destabilise" single models of Dls, and forced them evolve and change by exerting pressure on local authorities to respond to regional calls with a permanent change based on the innovation proposed - Lazio and Sicily have contributed to the "stabilisation" of PB as an important reference for what policymakers have imagined as a real culture of participation. However, the Sicilian mechanisms seem to be more effective due to the fact that it flatters

${ }^{26}$ See the annual Reports in Tuscany between 2014 and 2019 (http://www.consiglio.regione.toscana.it/oi) default?idc=47\&nome=aut_rapporti).

${ }^{27}$ See: Decree n. 435/2019 and the connected debate in the Stability Law proposal on: webcache.googleusercontent.com/search?q=cache:1oLekjvADFIJ:www.asael.pa.it/filedown.asp\%3Fs\%3D501\%26I\%3D1+\&cd=4\&hl= $p t-P T \& c t=c / n k \& g l=p t$. 
and attracts municipalities with concrete support destined to all. This "open-door" approach becomes a concrete leverage for mayors to behave in line with the ratio legis and its goals, and not only with its formal lettering [Int. 5]. Somehow, one could say that the real peculiarities of the Sicilian law are that: (1) all municipalities were offered the opportunity to receive support for their PB (while, in other regions, annual "calls for projects" could only benefit a limited number of cities); and (2) the way in which the support was presented (an added contribution, which could be revoked after careful verification of legitimacy with respect to its requirements) ended up being more effective in convincing a larger number of mayors to be more participatory.

Due to these interesting aspects, the Sicilian legal framework deserves more of literature's attention and careful monitoring, to understand which qualitative transformations the processes formally undertaken in these 6 years had undergone. But, unfortunately (unlike all the other laws, which have created offices or authorities that are in charge of accompanying and monitoring their outcomes and impacts), in contrast Sicily has failed to do this. In a very similar way, Poland has also failed to grant rural PB an incrementally growing quality that the central government is co-funding through the Solecki Fund Law [Bednarska-Olejniczak D. and Olejniczak J., 2018], as it has not established real supporting and monitoring structures to accompany their development and diffusion.

\section{AN OPEN CONCLUSION: SOME POTENTIAL DIRECTIONS FOR FUTURE RESEARCH PROJECTS}

In Italy - in the last two decades - there have been some attempts made to map participatory budgeting experiences, as literature and political debate recognised that they represented a growing and meaningful investment of many political/administrative authorities. Despite that each mapping exercise had to recognise its limits (due to the lack of common spaces of data convergence) and the short-duration of its validity (as datasets quickly become old with the fast transformations affecting the geographies of the cases' distribution), this exercise has been carried out repeatedly, by different actors. The same has barely happened to other Democratic Innovations, which have grown, spread and declined countrywide, without becoming the object of specific research aimed to visualise and understand their distribution, and the motivations behind the intensity and density of their changing geographies (partial exceptions are, maybe, represented by Agendas XXI, the Local Action Groups linked to the EU-based Leader funding scheme, and some more institutionalised processes of planning through integrated territorial tools, at the end of the 90s). Undoubtedly, PB has attracted more attention, deserving it for its varied impacts, as for the relatively easier "recognisability" it has shown, in relation to other DIs which are more difficult to define and catalogue in visible sub-models. Despite this, the mapping exercises on PB has rarely proved able to create traceable "series" of data, which could easily be updated, compared and interpolated with other phenomena, as that represented by the gradual diffusion of regional legal frameworks devoted to increasing the number of experiments of citizens' engagement in local policies and projects, and to contribute to the creation of a more intense participatory culture in managing public affairs. Indeed, the collaborative planetary project of the "PB World Atlas" has offered an unmissable opportunity to establish, also in Italy (as it already exists in Portugal), a collectively-produced database and a large national workforce of researchers, which could contribute - to the future - with comparative analyses which can go beyond the mere mapping of the changing geographies of PBs, to understand other concurrent and interlinked dynamics, as those related to the fast-evolving effects of legislative acts to regulate participation.

Within this effort, the authors of this article have been trying to kick-off the first step of an exploratory analysis that could respond to the doubts on whether, and to what extent, 
the presence of normative frameworks impacts the diffusion of PB. As expected, statistical occurrences seem to confirm a positive correlation between the number of PBs and the existence of regional laws, and proved this both in the case of apparently mandatory laws (as those approved in Sicily, in 2014, which was implemented slowly, and has been modified and clarified gradually in the last six years), but also in the cases of regulatory measures based on incentives and rewards provided by the region - through different mechanisms to sub-regional administrative authorities (municipalities and their associations, but also some provinces).

Indeed, this mapping - is more than having a conclusive nature - can be viewed as a starting point for a wide range of future research. In fact, it opened a Pandora box of questions related not only to the quality of PB experiences that regional laws on participation foster, but to the extent to which the latter can induce resilience, long-duration and sustainability in PBs, as well as stimulate cross-fertilisation and hybridisation between PBs and other Democratic Innovations with different and complementary methodologies. Under this perspective, looking back to previous studies provides a diagnostic series of fast-moving dynamics of densification and rarefaction of PBs in single areas or regions (also independently from the existence of regional laws), that address questions related to the convergence, divergence of different overlapping movements related to networking, communication and emulation mechanisms that propel political authorities into action. The same regions have been protagonists of imitative dynamics and created spaces for crosspollination and mutual learning of their experiences, which partially explain the different numbers that have emerged in quantitative studies that refer to different time periods.

In such a perspective, this article confirms that regional laws are an important and impactful phenomenon, necessary to enlarge the scope of participatory experiments, but are neither sufficient in consolidating single typologies of Democratic Innovations, nor do they explain the multiple reasons that preside to their expansion, shrinking and/or hybridisation with other participatory and deliberative methodologies. What is definitely needed, for the future - both from Regional Governments and researchers who are committed to analysing these inter-connected dynamics (in a more adequate and rigorous comparative form) - is the consolidation of observatories or similar structures. The latter could be a pivotal resource to better monitor PBs and other DIs from a quali-quantitative perspective, acting as spaces of permanent monitoring and oversight, but also as arenas that favour mutual learning and shared forms of collaborative assessment and permanent re-thinking of the practices, and of the same regulatory and incentivising policy and legal frameworks. 


\section{References}

Abrantes P., Lopes A., and Baptista J.M. (2018). 'The Schools Participatory Budgeting (SPB) in Portugal' in Dias N. (org.), Hope for Democracy. 30 Years of Participatory Budgeting Worldwide. Faro: Oficina/Epopeia, pp. 469-476.

Allegretti G. (2003). L'insegnamento di Porto Alegre: autoprogettualità come paradigma urbano. Firenze: Alinea (Luoghi, 10. Rappresentazioni).

Allegretti G. (2011a). 'Descentralización infra-municipal y participación en Italia y Portugal. Una lectura "en movimiento" entre el conflicto y la cooperación’. Voces, 5, 42-63.

Allegretti G. (2011b). 'Le processus d'economie participative de la Region Lazio. Quand l'experimentation devient le symbole d'une gestion politique'. In: Y.Sintomer and G.Talpin (eds.), La democratie participative au-de-la de la proximité. Le Poitou-Charentes et l'echelle regionale. Rennes: Presse Universitaire de Rennes.

Allegretti G. and Allulli M. (2007). “Os Orçamentos Participativos em Itália: Uma 'ponte’ para a construção do Novo Municipio”. Revista Crítica de Ciências Sociais (2007): 101-130. http://doi.org/10.4000/rccs.789.

Allegretti G. and Casillo I. (2015). 'Promover a Cultura da Participação a partir do nível regional. 0 caso da Toscânia'. REDE: reflexões (in) oportunas, 2/2015, pp. 24-31.

Allegretti G., Copello K. (2018). Winding around money issues. What's new in PB and which windows of opportunity are being opened? In Hope for democracy: 30 years of participatory budgeting worldwide edited by Dias N. (ed.), pp. 34-53. Faro: Epopeia Records, Oficina.

Allegretti G. and Stortone S. (2014). Participatory budgets in Italy: reconfiguring a collapsed panorama. In: N. Dias (ed.). Hope for Democracy. 25 years of Participatory Budgeting worldwide, Sao Bras deAlportel: In Loco.

Allegretti G., Matias M. and Schettini Martins E. (2010). 'Orçamentos Participativos e o recurso a tecnologias de informação: uma relação virtuosa?', Revista Crítica de Ciências Sociais, vol. 91, pp. 169-188.

Allegretti G., Secchi M. and Tang A. (2016). 'Hybrid scales of citizen engagement: how technologica integration can scale-up participatory processes?' In R.N. Balbim (ed.) The geopolitics of cities: old challenges, new issues. Brasília: Ipea, pp. 211-242.

Allegretti G., Barragan V., Bou J. et al. (2012). Estudio comparativo de los presupuestos participativos en Republica Dominicana, Espana y Uruguay. Malaga: CEDMA.

Allegretti G., Herzberg C. (2004). Participatory budgets in Europe. Between efficiency and growing local democracy. TNI.

Allegretti U. (1996). Amministrazione pubblica e costituzione. CEDAM, Padova.

Allegretti U. (2006). 'Basi giuridiche della democrazia partecipativa in Italia: alcuni orientamenti'. Democrazia e diritto, n. 3, pp. 151-166.

Allegretti U. (2010). L'amministrazione dall'attuazione costituzionale alla democrazia partecipativa. Milan: Giuffrè.

Allegretti U. (2011). ‘Democrazia partecipativa'. Enciclopedia del diritto. Annali IV. Milano: Giuffré, pp. 295-308.

Angeloni L., Festa D., Goñi Mazzitelli A. et al. (2013). Democrazia emergente. La stagione dei Bilanci Partecipativi a Roma e nel Lazio. Napoli: Gangemi.

Appadurai A. (1990). Disjuncture and Difference in the Global Economy. Theory, Culture \& Society. 7: 295-310.

Bächtiger A, Dryzek J.S., Mansbridge J. et al. (org.) (2018). The Oxford Handbook of Deliberative Democracy. Oxford. Oxford Scholarship online.

Baiocchi G. (2005). Militants and Citizens: Local Democracy on a Global Stage in Porto Alegre. Redwood: Stanford University Press University Press.

Baiocchi G., Ganuza E. (2017). Popular Democracy: The Paradox of Participation. Redwood: Stanford University Press.

Bassoli M. (2012). 'Participatory Budgeting in Italy: An Analysis of (Almost Democratic) Participatory Governance Arrangements'. International Journal of Urban and Regional Research, 36(6), pp. 1183-1203. https://doi.org/ 10.1111/j.1468-2427.2011.01023.x.

Bassoli M. (2018). Democrazia diretta. Riflessioni a partire dal bilancio partecipativo. Roma: Aracne.

Bassoli M., Graziano P., Perini L., et al. (2021). 2019 Dataset of Participatory Budgeting in Italy [Data set]. Centro di Ateneo per le Biblioteche dell'Università degli Studi di Padova. https://doi.org/10.25430/RESEARCHDATA. CAB.UNIPD.IT.00000457. Retrieved March 15, 2021, from https://oibp.bipart.it/.

Bednarska-Olejniczak D. and Olejniczak J. (2018). 'Participatory Budgeting in Poland in 2013-2018 - Six Years of Experiences and Directions of Changes'. In Dias N. (org). Hope for Democracy. 30 years of participatory budgeting worldwide. Faro: Oficina/Epopeia, pp. 337-354.

Bifulco R. (2011). ‘Democrazia deliberativa'. In Enciclopedia del diritto, Annali IV. Milano: Giuffré.

Blondiaux L. and Sintomer Y. (2009). 'L'impératif délibératif', Rue Descartes, 2009(1), no. 63, pp. 28-38. https://doi.org/10.3917/rdes.063.0028.

Bobbio L. (2017). 'La partecipazione dei cittadini nello Statuto della Regione Piemonte'. In Dogliani M., Luther J., and Poggi A. (orgs.) Lineamenti di Diritto Costituzionale della Regione Piemonte". Giappichelli, Torino.

Bortolotti F., Corsi C. (org.) (2012). La partecipazione politica e sociale tra crisi e innovazione. II caso della Toscana. Ediesse. 
Ciaffi D. (2019). 'Sharing the Commons as a ‘New Top' of Arnstein's Ladder of Participation. Built Environment, Vol. 45(2), pp. 162-172(11). https://doi.org/10.2148/benv.45.2.162.

De Nictolis E. and laione C. (2016). 'Bologna: un modello di cooperazione tra amministrazione, associazioni, cittadini'. Equilibri, 1/2016, giugno, pp. 41-44.

Dias N. (2018). 'Hope for democracy. 30 Years of Participatory Budgeting Worldwide'. Faro: Epopeia/Oficina.

Dias N., Sahsil E., Simone J. (org.) (2019). The Participatory Budgeting World Atlas 2019. Faro: Epopeia/Oficina.

Falanga R. and Fonseca I. (2020). The Scaling-up of Participatory Budgeting. Insights from Brazil and Portugal. In Lauria M. and Schively Slotterback C. (eds.) Learning from Arnstein's Ladder. From Citizen Participation to Public Engagement. New York: Routledge.

Fedozzi L. (2000). Poder da Aldeia. Gênese e História do Orçamento Participativo de Porto Alegre. TOMO editorial.

Fernandes E. (2007). 'Constructing the 'Right To the City' in Brazil'. Social \& Legal Studies, 16(2), $201-219$. https://doi.org/10.1177/0964663907076529.

Fernandes E. (2021, forthcoming). Interview “How can URBiNAT contribute to the right to the city?”. D1.8 Urbinat Project deliverable. Coimbra: CES.

Fishkin J. (2018). Democracy When the People Are Thinking: Revitalizing Our Politics Through Public Deliberation. Oxford: Oxford Scholarship online.

Floridia F. (2013). 'Le 'buone ragioni' di una legge: dilemmi e argomenti sul senso della partecipazione (e sui modi del governare')'. In Morisi M., and Perrone C. (org.). Giochi di potere. Partecipazione, piani e politiche territoriali. Torino: UTET Università.

Fung A. (2015). "Putting the Public Back into Governance: The Challenges of Citizen Participation and Its Future". Public Administration Review, vol. 75/4, July/August 2015, pp. 513-522.

Fung A., Wright E.O. (2002). Deepening Democracy: Institutional Innovations in Empowered Participatory Governance. London: Verso Press.

Ganuza E. and Francés F. (2012). El círculo virtuoso de la democracia: los presupuestos participativos a debate. Madrid: CIS.

Ganuza E., Baiocchi G. (2012). The Power of Ambiguity: How Participatory Budgeting Travels the Globe. Journal of Public Deliberation, 8(2), 8.

Geissel B. (2013). On the Evaluation of Participatory Innovations - A Preliminary Framework. In B. Geissel, M. Joas (eds.). Participatory democratic innovations in Europe. Improving the quality of democracy? Berlin: Barbara Budrich Publisher.

Genro T. (1997). 'O Orçamento Participativo e a Democracia'. In Genro T. and de Souza U., Orçamento Participativo. S. Paulo: Fundação Perseu Abramo.

Keane J. (2018). Power and Humility. The Future of Monitory Democracy. Oxford: Oxford University Press.

Lewanski R. (2013). 'Institutionalizing Deliberative Democracy: the 'Tuscany laboratory". Journal of Public Deliberation, 9(1).

Massarenti F. (2017). 'Le circoscrizioni di decentramento in Italia. L'evoluzione normativa, i fattori di crisi e le prospettive future'. Istituzioni del federlaismo, n. 1/2017, pp. 251-282.

McNulty S. (2018). 'Mandating PB: Evaluating Fifteen Years of Peru's National Participatory Budgeting Law2. In Dias N. (org.). Hope for Democracy. 30 Years of Participatory Budgeting Worldwide. Faro: Oficina/Epopeia, pp. 147-159

Minson J. (1993). 'The Participatory Imperative'. In Minson J. Questions of Conduct: Sexual Harassment, Citizenship, Government. Language, Discourse, Society. Palgrave Macmillan, London. https://doi.org/10.1007/9781-349-22882-9_8.

Moro G. (2020). Cittadinanza. Milan: Mondadori Universitá.

Nitzche P., Pistoia A. and Elsäßer M. (2012). 'Development Of An Evaluation Tool For Participative E-Government Services: A Case Study Of Electronic Participatory Budgeting Projects In Germany'. Revista Administratie Si Management Public, vol. 2012(18), pp. 6-25.

No W. (2018). 'History and Issues of Participatory Budgeting in South Korea'. in Dias N. (org.). Hope for Democracy. 30 Years of Participatory Budgeting Worldwide. Faro: Oficina/Epopeia, pp. 147-159.

Oliveira O. (2017). International Policy Diffusion and Participatory Budgeting. Ambassadors of Participation, International Institutions and Transnational Networks, London: Palgrave McMillan. https://doi.org/10.1007/9783-319-43337-0.

Papa A. (2020). 'O direito de ser informado no âmbito da proteção multinível da liberdade de expressão. Revista Brasileira De Direitos Fundamentais \& Justiça, 13(41), pp. 93-114. https://doi.org/10.30899/dfj.v13i41.817.

Pateman C. (2012). APSA Presidential Address: Participatory Democracy Revisited. Perspectives on Politics, 10(1), 7-19. Retrieved March 15, 2021. http://www.jstor.org/stable/23327060.

Picchi M. (2012a). II diritto di partecipazione. Milan: Giuffrè.

Picchi M. (2012b). "Il "Sostegno" ai progetti di bilancio partecipativo attraverso la legge regionale toscana n. 69/2007'. In Bortolotti F., Corsi C. (org.) La partecipazione politica e sociale tra crisi e innovazione. II caso della Toscana. Ediesse, pp. 269-296.

Ravazzi S. (2007) Civicrazia. Quando i cittadini decidono. Roma: Aracne. Available at: http://www.libreriauniversitaria.it/civicrazia-quando-cittadini-decidono-ravazzi/libro/9788854805118. 
Ravazzi S., Pomatto G. (2017). Partecipare alle scelte pubbliche. L'esperienza del Bilancio deliberativo di Torino. Torino: Comune di Torino.

Revel M., Blatrix C., Blondiaux L. et al. (orgs.) (2007). Le débat public: une expérience française de démocratie participative. Paris: La Decouverte.

Rispoli F. (2012). 'La carta del Nuovo Municipio'. PRISMA Economia - Societá - Lavoro, vol. 2012(2), pp. 54-67.

Santos B., Avritzer L. (2007). 'Introduction: Opening Up the Canon of Democracy'. In Santos B. (ed.) Democratizing Democracy. Beyond the Liberal Democratic Canon. London: Verso, pp. xxxiv-Ixxiv.

Sgueo G. (2011). 'La democrazia partecipativa nelle regioni. La legge n. 14 del 2010 della Regione Umbria'. Quaderni Regionali, II/2011, pp. 559-575.

Sintomer Y. (2007). Le pouvoir au peuple. Jurys citoyens, tirage au sort et démocratie participative. Paris: La Découverte.

Sintomer Y. et al. (2012). 'Transnational Models of Citizen Participation: The Case of Participatory Budgeting'. Journal of Deliberative Democracy, 8(2), p. 9. https://doi.org/10.16997/jdd.141.

Sintomer Y. and Allegretti G. (2009). I Bilanci Partecipativi in Europa. Roma: Ediesse.

Sintomer Y., Allegretti G., Herzberg C.et al. (2013). Learning from the South: Participatory Budgeting worldwide - an Invitation to global cooperation. Bonn, Germany: Service Agency for Communities.

Smith G. (2009). Democratic Innovations. Designing Institutions for Citizen Participation. Cambridge: Cambridge University Press.

Sorice M. (2019). Partecipazione democratica. Teorie e problemi. Mondadori Università.

Stoker G. (2018). 'Governance as theory: five propositions'. International Social Science Journal, vol. 68, iss. 227-228, pp. 15-24.

Stortone S. (2019). 'Participatory Budgeting Data'. In Dias N., Sahsil E., Simone J. The Participatory Budgeting World Atlas 2019, pp. 164-165.

Stortone S. and Allegretti G. (2018). Participatory Budgeting in Italy. Towards a Renaissance? In Dias N. (org.). Hope for Democracy. 30 Years of Participatory Budgeting Worldwide. Faro: Oficina/Epopeia, pp. 289-311.

Stortone S. and De Cindio F. (2016). 'Styles of Online Participation in the Monza Participatory Budgeting', in. IEEE, pp. 17-24. https://doi.org/10.1109/CeDEM.2016.32.

Stortone S., Pittella G. and Bassoli M. (2021). 2018 Dataset of Participatory Budgeting in Italy [Data set]. Centro di Ateneo per le Biblioteche dell'Università degli Studi di Padova. https://doi.org/10.25430/RESEARCHDATA.CAB. UNIPD.IT.00000469, Retrieved March 15, 2021, from https://oibp.bipart.it.

Valastro A. (2016). 'La democrazia partecipativa alla prova dei territori: tendenze e prospettive dei regolamenti comunali'. Osservatoriosullefonti.it, fasc. 3/2016.

Valastro A. and Carlone U. (2019). Partecipazione e politiche sociali in Umbria. Strumenti tradizionali e tendenze innovative. Morlacchi Ed.

Vandelli L. (2015). Il sistema delle autonomie locali. Bologna: Il Mulino.

World Bank (2010). Peru: Evaluación del presupuesto participativo y su relación con el presupuesto por resultados. Washington, D.C.: The World Bank.

\section{Information about the authors}

Giovanni Allegretti (Prof., Arch., PhD, Senior Researcher)

Centre for Social Studies, University of Coimbra Apartado 3087, Largo Dom Dinis, 3000-995 Coimbra, Portugal

Matteo Bassoli (PhD, Asst Prof.) Department of Political Science, Law, and International Studies URBES Observatory on Urban Policies, CISR Regional Studies Center University of Padova Via del Santo, 2835123 Padua, Italy

Greta Colavolpe (M.Sc)

Department of Political Science, Law, and International Studies, University of Padova

Via del Santo, 2835123 Padua, Italy

Article submitted March 4, 2021

Approved after reviewing March 31, 2021

Accepted for publication April 14, 2021 
https://doi.org/10.31107/2075-1990-2021-2-25-45

\title{
В шаге от институционализации? Опыт партисипаторного бюджетирования в пяти регионах Италии
}

Ажованни Амегретти, профессор, архитектор, $P h D$, старший научный сотрудник Центра социальных исследований Университета Коимбры, Коимбра, Португалия

E-mail: giovanni.allegretti@ces.uc.pt, ORCID: 0000-0001-6234-5168

Маттео Бассоли, PhD, ассистент профессора кафедры политологии, права и международных исследований, Обсерватория городской политики URBES, Центр региональных исслеАований ЦнСИ Университета Падуи, Падуя, Италия

E-mail: matteo.bassoli@unipd.it, ORCID: 0000-0003-3601-9099

Грета Колавольпе, магистр Аепартамента политологии, права и межАународных исследований Университета ПаАуи, ПаАуя, Италия

E-mail: gretacolavolpe@gmail.com, ORCID: 0000-0002-9060-9842

\begin{abstract}
Аннотация
В последние несколько лет Италия стала местом реализации ряда демократических инноваций, в том числе на региональном и муниципальном (субнациональном) уровнях власти в различных частях государства. Расширение сферы применения партисипаторного бюджетирования сопровождалось, что особенно примечательно, принятием региональных законов, которые утверждали распространение культуры активного гражданского соучастия. Аанная статья посвящена обзору партисипаторного бюджетирования в различных частях современной Италии и анализу того, какую Аополнительную ценность привносит существование подобной гражданской практики, основанной на соучастии граждан на региональном уровне, и в каких формах она может проявляться. Появмение во Всемирном атласе партисипаторного бюджетирования раздела, посвященного Италии, позволяет оценить вклаА расширения правового регулирования в укоренение практик участия граждан в бюджетных решениях, особенно в небольших муниципалитетах. Подвергнув пристальному вниманию отдельные регионы Италии (такие как Сицилия, Эмилия-Романья, Апулия и Тоскана, Аацио) в последние несколько лет, авторы статьи пришли к убеждению, что формализация практики участия в правовых рамках сегодня является важным, но недостаточным фактором формирования культуры гражданского участия на локальных территориях. Аанному процессу необходимо постоянное, в режиме мониторинга, сопровождение и подробные исследования, направленные на выявление проблем и дополнительных преимуществ регионального правового регулирования.
\end{abstract}

Киючевые слова: партисипаторное бюджетирование, институционализация, региональные законы, стимулы к участию, вовлечение граждан, государственная политика, гражданское участие

JEL: 035, K30, N44, L38

А^я цитирования: Allegretti G., Bassoli M., Colavolpe G. On the Verge of Institutionalisation? Participatory Budgeting Evidence in Five Italian Regions. Financial Journal, 2021, vol. 13, no. 2, pp. 25-45 (In Russ.). https://doi.org/10.31107/2075-1990-2021-2-25-45.

(C) Allegretti G., Bassoli M., Colavolpe G., 2021

Статья поступила в редакцию 04.03.2021

ОАобрена после рецензирования 31.03.2021

Принята к публикации 14.04.2021 